\title{
The Story of the National Materials Advisory Board in the United States
}

The National Materials Advisory Board (NMAB) functions under the auspices of the National Research Council (NRC), the operational arm of the U.S. National Academies. Composed of prominent researchers and research managers who represent the breadth of materials science and engineering, it performs independent peer-reviewed studies of aspects of materials science and engineering for a broad spectrum of sponsors.

In many ways, the birth and development of NMAB illustrate the establishment of materials science and engineering as a discipline. NMAB's origins can be traced to the Second World War era, when the overarching importance of materials to the U.S. national defense was recognized by the Department of Defense's (DoD) formation of the War Metallurgy Committee. The committee delivered recommendations to the $\mathrm{Na}$ tional Defense Research Committee of the Office of Scientific Research and Development throughout the war.

During the early 1950s, numerous materials shortages were created by the demands for mobilization and weapons production. Postwar research gave rise to new concepts that placed entirely new demands on materials and processing. The developing Cold War and Korean conflict heightened the need to reduce these concepts to manufacturing practice.

While the nuclear program of the Second World War gave rise to tremendous advances in the understanding of some materials, other aspects of materials understanding lagged far behind. This led the Research and Development Board of the DoD to ask the National Academy of Sciences to establish the Metallurgical Advisory Board (MAB) in 1950, in order to advise the DoD. The first meeting of the MAB took place in early 1951. In the early years, the board responded to requests as an ad hoc organization. Later, the board expanded its focus beyond metals, changing its name to the Materials Advisory Board in 1954. "National" was added to the name in 1968.

Early studies centered primarily on the analysis of resources and needs and the development of functional substitutes for critical materials such as nickel, chromium, columbium, and vanadium, which were required for jet engines, weapons, and armor. Later in the 1950s and into the 1960s, attention to the issues surrounding beryllium (processing, toxicity, and properties) came to the fore. In the 1960s, issues of materials characterization and ceramic processing were the topics of important studies.

In many ways, the birth
and development of NMAB
illustrate the establishment
of materials science and
engineering as a discipline.

The 1970s marked the emergence of materials science and engineering as a distinct discipline. In 1974, the NMAB Committee on the Survey of Materials Science and Engineering released a mammoth four-volume report titled "Materials and Man's Needs" in which it declared, "Materials science and engineering is emerging....as a coherent doctrine or technical field with deep intellectual roots, which promises new contributions, on a practical time scale, to the nation's prosperity, security, and quality of life."

The spectrum of materials issues addressed by NMAB in the 1970s through the 1990s reflects the broadening palette of materials scientists and engineers: fire safety aspects of polymeric materials (which resulted in a redesign of the train cars for the Washington, D.C. Metro System); cement and concrete R\&D in the United States; grain-elevator explosions; stone building and monument conservation; titanium; high-technology ceramics; competitiveness of the U.S. minerals and metals industries; counterfeit deterrence in currency; microelectromechanical systems (MEMS); aging of U.S. Air Force aircraft; hierarchical structures in biology as a guide for new materials technology; liquid-crystalline polymers; and the impact of supercomputing capabilities on U.S. materials science and technology. In all, over 500 reports have been issued under the auspices of NMAB. A list of reports issued since 1995 are available on-line at http://www. nationalacademies.org/nmab/.

So what has NMAB done lately? Two reports have just been released. Materials Research to Meet 21st Century Needs is the report of a three-year study that addresses the materials research investments that will be required for DoD to be able to meet its goals for the nation's defense in 2020 and beyond (see the December 2002 issue of MRS Bulletin, p. 947). Materials and Society: From Research to Manufacturing is the report of a forum held March 27-28, 2002, in Washington, D.C., that brought together government policymakers, members of the materials research and manufacturing communities, and end-users of materials to review, consider, and discuss the current state of materials science and engineering in the United States and the challenges in the coming years.

JULIA M. PHILLIPS AND

TONI MARÉCHAUX

Julia M. Phillips is chair of the National Materials Advisory Board and director of the Physical and Chemical Sciences Center at Sandia National Laboratories in Albuquerque, N.M.

Toni Maréchaux is staff director of the National Materials Advisory Board. 